Available online: 7. December 2017

\title{
INDICATORS OF REGIONAL INEQUALITY IN SERBIA
}

\author{
Marko Joksimović ${ }^{* 1}$, Rajko Golić ${ }^{*}$ \\ "University of Belgrade - Faculty of Geography, Belgrade
}

\begin{abstract}
The diversity of spatial units of the Republic of Serbia is caused by several types of regional inequality. Only some of indicators of inequality between the regions can be considered developmental problems. In this paper indicators are distinguished by which it is possible to isolate and compare the regions of Serbia according to different criteria. This approach required use of several different methodologies from the domain of geography, economics and environmental protection. Results point to Republic of Serbia as a polarized space with a trend of concentration of population and economic activity in certain regions, and at the same time, lagging of other regions.
\end{abstract}

Key words: Serbia, region, landscape, inequality, indicator, GINI index.

\section{Introduction}

Regional inequalities are result of differences between regions or their essence as distinct territorial units separated by homogeneity or functionality. Inequalities come from natural features: geological structures, relief, climate, hydrography, plant and animal life as well as land. Regional inequalities should not be identified with regional problems (erosion, weather and hydrological disasters, seismic hazards, economic underdevelopment, demographic recession and environmental conditions). More precisely, indicators for determining regional inequalities reveal the problems of individual regions in a country.

${ }^{1}$ Corresponding author: M. Joksimović, University of Belgrade - Faculty of Geography, Studentski trg 3/III, 11,000 Belgrade, Serbia; e-mail: dellmare10@gmail.com 
Some of the consequences of regional problems such as population migration, depopulation and poverty are becoming state problems. The problems of local self-governments point to development problems within the region. The two regions need not have problems to be unequal according to a particular criterion. However, due to significant disproportions (usually in economic terms), the economically backward regions are categorized as problematic.

An important context for determining inequality is the perception of the local population about identity, ie. the typical features of the region they live in. Features include size, content, advantages, constraints and problems of the region (Stanners \& Bourdeau, 1995). The basis for spatial planning, environmental protection and prioritization of economic activities are established by separating the types of landscapes (landschafts) on the principle of homogeneity of typical characteristics (relief, climatic characteristics, vegetation, types of habitats, settlements and economic activities that determine the use of land). According to the project „European Landscape Character Areas", several criteria have been proposed for separating types of regions based on GIS data: biogeographic zones, digital elevation model of terrain, type of substrate and land use (Mücher, Klijn, Wascher \& Schaminée, 2010; Wascher, 2005). The proposed types of areas point to unequal resources and conditions between regions in Europe and within the region.

Within a country, there are economic inequalities: at the level of local self-government (communities), sub-regions and regions. This latter not only represents a spatial dimension of unevenness, but reveals important links and threats to the stability of the state (it is revealed that regional inequality leads to the risk of secessionist conflict) (Deiwiks, Cederman \& Gleditsch, 2012). Examples from the world are regions - poles of development with a high degree of autonomy: Catalonia, Basque, Istria, Hong Kong, Macao, Taiwan, Zanzibar and others. The main causes of inequality among the regions of Serbia are following: unfavorable demographic trends, high and uneven unemployment rate, small scale industrial production, inadequate infrastructure and others (Тошић, Лукић \& Ћирковић, 2005).

By the mid-20th century, the polarized development of the region was investigated most from an economic point of view. In order to investigate the causes, determine the legality and consequences of the uneven development of the region, theories and concepts such as the concept of circular cumulative causality and the theory of poles of growth and development (Тошић, 2012) are set. Williamson (1965) was the first to suggest the idea of determining inequality between regions according to the number of inhabit- 
ants within the state. Since then, the methodologies for determining uneven development have been constantly evolving.

There are several methods for extracting problem regions. In order for regions to be comparable, it is necessary for indicators to be uniform. Due to the simplicity of methodology and data availability, the Economic Sector Model was used to analyse the degree of development of municipalities, regions and countries. The development stages of the region were determined on the basis of the ratio of the share of the employed population in certain sectors. The starting point for this model is the hypothesis that income and employment across sectors are complex and dynamic categories that condition development processes (Bradford \& Kent, 1977). According to Borgegård, Håkansson and Malmberg (1995), the geographers identified several of main factors that influence the concentration of the population or its dispersion. These are: demographic (natural growth, demographic structures, social capital, migrations, etc.), economic (employment dynamics, population income, housing costs, state of transport systems, location of physical resources, accessibility to larger settlements), social-psychological (the need of social groups or individuals to change the place of residence, the attitude of the individual towards different geographical locations, different lifestyles and the environment) and political factors (population or family policy, social protection, local and regional economies policy, etc.).

Common to the emergence of the regional inequality and problem regions is that the state takes planned interventions. Hagel highlighted four main categories: economically underdeveloped areas; densely built and overburdened areas; areas of degraded natural environment; and areas endangered by natural disasters (Vresk, 1990). In strategic documents, problem regions are adapted to the political, social and economic systems of the countries in which they are determined (SGRS, 2005; SLCG, 2011). The European Commission has developed a Regional Competitiveness Index (RCI) to determine the benefits and constraints of the region in the Member States of the European Union. The index is a synthesis of several variables: institutions, macroeconomic stability, infrastructure, health, education, labour market efficiency, market size, technological advancement and innovation (Annoni \& Djikstra, 2013). Analysing the research by numerous authors, Тошић (2012) lists four groups of regions „whose developmental harmonization treats regional planning and regional policies": regions dominated by agriculture with a relatively high share in production, income and labour force employment; regions whose progress has previously been based on mining and industrial sectors that are in recession; regions with high concentrations of 
production and the burden of overpopulation, traffic congestion and environmental pollution, with a pressure on public infrastructure; boundary and isolated regions away from development centres.

According to the above, there are no ideal indicators but the best-fit indicators for regions. In the statistical yearbooks of Serbia during the first years of the 21st century, indicators of regional inequality were used (P3C, 2002):

- National income per capita,

- Number of employees per 1,000 inhabitants,

- Turnover in retail trade per capita,

- Number of telephone subscribers per 1,000 inhabitants.

Today, the last of these indicators seems irrational since the fixed telephony has been pushed by the mobile as well as by a large number of Internet users. The given example points to the limited methodologies for calculating regional inequality.

The determination of regional inequality also has a normative side. Within the framework of the Law on Regional Development, adopted in 2009 and supplemented in 2010, one of the goals was to reduce regional and interregional inequalities by encouraging the development of underdeveloped, devastated industrial and rural areas (SGRS, 51/2009, 30/2010). Within the above mentioned, the Decree determining the methodology for calculating the level of development of the region and units of local self-government in which, as indicators of the degree of development, the following are allocated: demographic decline or growth; unemployment rate; and education level.

„The level of development of the region and local self-government units is a measure of the development of a certain region and a local self-government unit in relation to the country average; The level of development of the region and local self-government units shall be determined using the indicators of the development of the region and local self-government units, in accordance with this law, based on the data of the authority responsible for statistics."

"According to the degree of development, the regions are divided into two groups:

1. Developed regions, whose level of development is above the republic average of the gross domestic product per capita;

2. Underdeveloped regions, whose level of development is below the national average of the gross domestic product per capita." (SGRS, 42/2010) 
The average values at the republic level vary year by year and the data obtained are only relative and incomparable at the annual level. The problem of the mentioned methodology is also isolation in relation to the methodology of calculating inequality in the countries of the European Union.

The aim of this paper was to analyse the indicators of regional inequality in Serbia and point to their mutual correlation.

\section{Research methodology and indicators of regional inequality}

The research area is interregional (GINI on the whole Serbia level) and intraregional at the level of the NUTS 3 region and the landscape regions of Serbia. Time coverage of the survey was reduced to period 1991-2015 due to the lack of certain data at the regional level, as well as the unification of economic indicators (national income).

In order to extract the natural regions of Serbia, generalized maps of Europe and Serbia were used as well as sources gathered by field research and satellite-image analysis: map of potential natural vegetation of Europe (Bohn, Gollub \& Hettwer, 2000); map of the ecological zones of Europe (Metzger, Bunce, Jongman, Mücher \& Watkins, 2005); map of the European landscape types (Mücher et al., 2010; Stanners \& Bordeau, 1995); map of the climate types of Serbia (Milovanović, Ducić, Radovanović \& Milivojević, 2017); land use map (CORINE, 2012); and geomorphological map of Serbia (GEOLISS, 2017; Zeremski, 1990). The geomorphological regions of Serbia were isolated on the basis of homogeneity - spatial domination of typical genetic types of relief or relief forms relative to others (representation $>50 \%$ on a certain surface). For example, in the region of the Lower Pannonian Plain, more than $50 \%$ of the territory covers the fluvial-puddle bottom of the former Pannonian Sea, the loess plateau and the sandy terrains. In the region of the Pannonian Plain rim, more than $50 \%$ of the area is covered with marinelacustrine terraces and areas of moderate denudation and gully forming.

Demographic indicators were analysed in 1991-2015 period based on the estimated number of inhabitants on half of the year (P3C, 2016). For the analysis of the labour market, data on unemployed persons per 1,000 inhabitants were used at the district level. In order to analyse economic inequality of municipalities, GINI index is chosen - the measure of inequality in the distribution of revenues, which can range from 0 to 1 , where 0 represents the perfect equality, i.e. all persons in society have equal income. The value is 
closer to number 1, the inequality is higher. Obtained results of GINI values are expressed in percentages. The most common indicators used are national income per capita (NIPC) (Shankar \& Shah, 2003), regional gross domestic product (RGDP) per employee (Canaleta, Pascual Arzoz \& Rapún Gárate, 2004), or regional GDP per capita (Ezcurra \& Pascual, 2008; Lessmann, 2012; Rodriguez-Pose \& Gill, 2004). All of these indicators have particular advantages and constraints that depend on the flows of daily migrants or unequal employment. GNI coefficient limitations are related to changes in the relative incomes of individuals or individual population groups. In addition to the aforementioned, there is a problem of different sizes of the region. For countries with large regional differences in economic production and the number of inhabitants (Canada, China, Brazil) it is difficult to interpret indicators of regional inequality. In Serbia, which, according to the number of inhabitants, standing at the level of one NUTS 1 region, the relatively same natural and social factors have led to regional inequalities, which makes it easier to analyse and interpret the results of the analysis. The limitation for applying the GINI index method is the unevenly distributed natural conditions and resources. In the share of regional income, at the interregional level, mining municipalities (such as lignite and marl basins in Serbia) are far richer than others.

We used official databases of the Republic Statistical Office of Serbia (RZS). In addition to the analysis methods, comparisons, time series and GIS mapping techniques, a computer application for the GINI index and Lorenz curve was used (Rosenmai, 2017). Based on data on the number of inhabitants and national income, the national income per capita was calculated as well as the GINI index indicating deviation of income by municipalities (cities) and areas relative to the average value. National income per capita (NDS) was used as a basic indicator of inequality - an aggregate indicator of the achieved level of economic development.

The formula for calculating the GINI coefficient is:

$$
\text { GINI: }=\frac{2 \sum_{i=1}^{n} i y_{i}}{n \sum_{i=1} y_{i}}-\frac{n+1}{n},
$$

Where $y_{i}$ is the national income per capita of a particular region, and $n$ is the number of subregions or areas in the case of Serbia.

Data on national income at the level of municipalities (cities) exist until 2005. Since then, assuming that the processes of deepening economic inequalities have continued the budget revenues of municipalities (cities) (BP) and budgets of municipalities per capita (BPS) have been used. 
The methodology for calculating poverty in Serbia is based on the Household Budget Survey, which is conducted according to Eurostat and UN standards (P3C, 2011) as well as the Survey on Income and Living Conditions. The sample in 2016 was 5,554 households in the territory of four of the five regions of Serbia ${ }^{2}$ (PD10 br. 087, 2017). This ensures comparability of data, but the definition of poverty does not cover the entire population of the state. Poverty in Serbia determination is based on the consumption of households, ie. the amount of food and other current expenditure (gifts, production and purchased products). The total household consumption is distributed to household members by the equivalence scale where the household responsible member has a weight of 1 , adult members 0.7 and children (under 14 years) weighing 0.5 . The absolute poverty line is an indication of the minimum living standard and is based on a fixed consumer basket of foods to meet minimum living needs (increased by expenditure on clothing, footwear, hygiene, heat, etc.).

\section{Regional inequality in Serbia according to selected indicators}

Regional inequality in Serbia is based on the heterogeneity of natural characteristics: geological structures, relief, climate, hydrography and biogeography features.

On the basis of the dominant forms in the relief of Serbia (GEOLISS, 2017), eight homogeneous, geomorphological (morpho-structural) regions are marked off (Figure 1): 1. Pannonian lowland bottom (dominant forms: the fluvial - puddle bottom, loess plain, river terraces, alluvial floodplains, river terraces under the loess, the fluvial-denudation relief of the isolated mountains, modern floodplains, the valleys in the sandy deposits, the sand dunes and the marine - lacustrine terraces and fossil floodplains; 2. Pannonian lowland rim (marine-lacustrine terraces, fluvial-denudation forms, alluvial plains, river terraces, slips; 3. Mountains-basins-valleys (MBV) region (fluvial-denudation relief - intense rinsing and drainage, river terraces, glacial - nivation relief); 4. Dinaric karst belt (sinkholes, cenotes, karst fields, canyons, caves and dry valleys); 5. Carpathian-Balkan karst belt (sinkholes, cenotes, karst fields, canyons, caves and dry valleys); 6. Wallachian-Pontian lowland rim (marine-lacustrine terraces, fluvial-denudation relief - moderate rinsing and drainage, river terraces, landslides, ravines); 7. Basins of Kosovo and Meto-

\footnotetext{
${ }^{2}$ The Statistical Office of the Republic of Serbia does not have data for Administrative province of Kosovo and Metohija.
} 
hija (alluvial plains, river terraces, terrace cliffs and floodplains); 8 . Valleys of Serbian-Macedonian massif and Vardar zone (VSMMVZ) (alluvial plain, river terraces, proluvial lanes, piracies and terraced sections). Geomorphological regions provide different conditions for settling and developing economy. Pannonian plain and its periphery, valleys of VSMMVZ, Kosovo and Metohija basins are the most populated and economically most developed regions of Serbia. In addition to the advantages, there are limitations of every individual unit in geomorphological regions: slopes on the periphery of the Pannonian lowland, underground waters at lowlands, lack of surface water streams in karst belts, intense rinsing and dredging, high slope angles of relief as well as nivation processes in certain areas of the MBV region.

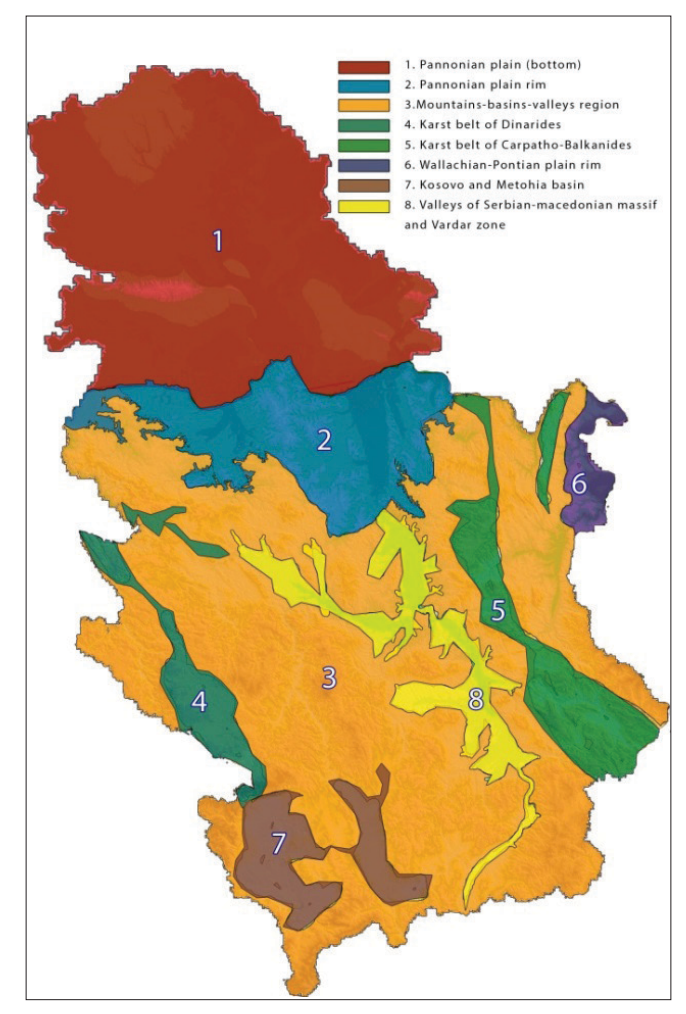

Figure 1 - Geomorphological regions of Serbia

Source: Map processed by paper authors based on data of GEOLISS, 2017.

Selected climate indicators of regional inequalities are air temperature and precipitation. Analysis included distribution of average monthly and average annual air temperature as well as precipitation for period 1961-2010, and accord- 
ing to Köppen methodology, 5 types of climate in Serbia are distinguished: Cfa - temperate warm and humid climate with hot air, $\mathbf{C f b}$ - moderately warm and humid climate with warm summer, Dfb - temperate cold and humid climate with warm summer, Dfc - moderately cold and humid climate with cold summer, Efc - cold and humid climate with a cold summer as well as a space with a maritime pluviometric regime (Milovanović et al., 2017). On the basis of spatial representation of the climate, four relatively homogeneous climatic regions can be distinguished, among which moderately warm and humid climate with a warm summer dominates (Figure 2). Moderately warm and humid climate with hot summer is mostly present in Belgrade heat island which comprises lowlands around Danube, Sava, Tamiš, Kolubara, Velika Morava river valleys. Moderately cold and cold climate is most common on altitudes and mountains above $1,000 \mathrm{~m}$. The moderately warm and humid climate with a warm summer and maritime pluviometric regime is distinguished in Metohija basin, parts of the Kosovo basin and the periphery of the Wallachian-Pontian plain.

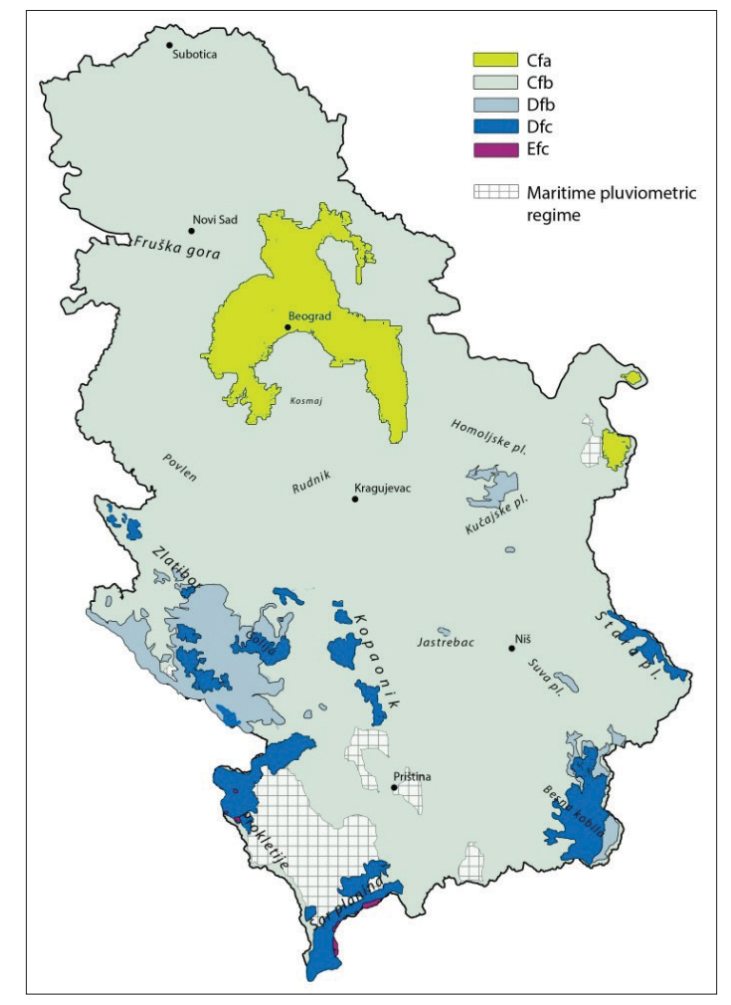

Figure 2 - Climate regions in Serbia

Source: Map processed by paper authors based on data of Milovanović et al., 2017. 
In order to protect and improve the environment and based on the distribution of plant and animal habitats, three biogeographic regions (EEA, 2016) can be identified in Serbia: 1. Pannonian, 2. Continental and 3. Alpine (Figure 3). A part from Serbia, they also spread in several European countries. The Pannonian region (also known as the Middle Danube Basin) (PBR) almost coincides with the extending of the bottom of the Pannonian Plain in Serbia. The largest part of the PBR area in Serbia is covered by cultivated land (arable land and gardens), then forest habitats, aquatic habitats and pastures. The Alpine region $(\mathrm{ABR})$ is in correlation with the Dinaric karst belt, high mountains and the spreading of cold climates in Serbia. The largest surface area of ABR in Serbia includes areas under forests, meadows, pastures and bare lands. Continental biogeographic region (CBR) encompasses diverse areas in Serbia south of PBR and east of ABR. Among the habitats, the most represented are forests, cultivated land, meadows and pastures. There are significant inequalities in socio-economic development between biogeographic regions. The most populous, most developed and richest in resources are regions concentrated within the PBR and the CBR valleys. On the other hand, low density of population, depopulation, extensive agriculture and traffic isolation are some of the characteristics of $\mathrm{ABR}$ and mountain areas of the CBR.

According to previous, polarization of Serbia on developed North and underdeveloped South is rooted in the natural environment. Various landscape units, the difference in the distribution of natural conditions and resources, demographic trends and economic determinants make it difficult to alleviate regional inequalities in Serbia.

Increase of population and dynamics of population structures are important factors of regional development. The growth is influenced by the natural growth of the population and immigration which implies an increase in the number of population of countries or regions can be stimulated and corrected during the time. Developed European countries give us example of demographic policy by which immigration is stimulated. As a result, economy and social system is sustainable. Demographic and social indicators and problems of Serbia are not consistent with the global trend of population increase but, to some extent, they are with the European one. Demographic policy as part of defined government measures of regional development were neglected in relation to the economic ones. Resolving demographic problems was locally, at the level of local self-governments in the form of parents' incentives to increase births or marriages. Therefore, Serbia is a phenomenon known as the economically poor society with a lack of children (Ђурђев и Арсеновић, 2015). 


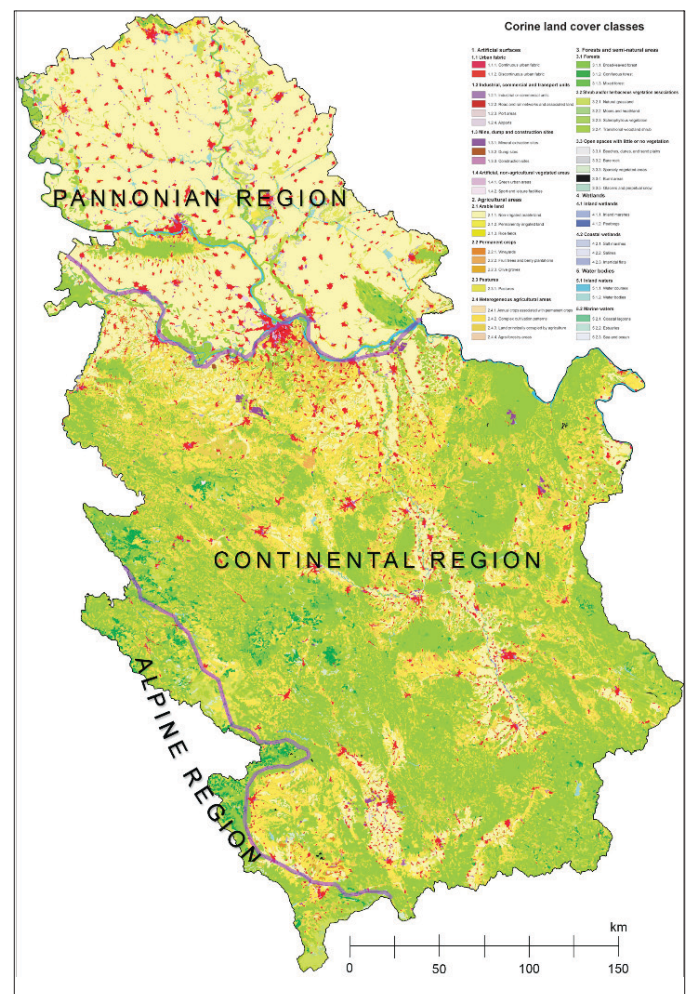

Figure 3 - Biogeographic regions of Serbia Source: Map processed by paper authors based on data of CORINE, 2012; EEA, 2016.

Depopulation caused by low and negative rates of natural growth and high average age of the population is basic demographic, economic and social problem in more than $50 \%$ of the municipalities of Serbia (P3C, 2016). This is the limiting factor of the economic development of the region and the state as a whole.

During period of 1991-2015, number of inhabitants of the Republic of Serbia has decreased. The average annual rate of population reduction was -2.6 $\%$. The reduction was recorded in 21 out of 24 districts (NUTS 3 region) in Serbia. An increase in the number of inhabitants was recorded only in Belgrade, South Bačka and Raška. At the level of municipalities (and cities as administrative centres), the increase in the number of inhabitants between the last two censuses was recorded in municipalities Surčin, Rakovica, Palilula, Zvezdara, Zemun, Grocka and Barajevo (more than 10\%), Novi Sad (14\%), Novi Pazar 
$(17 \%)$, Niš (4.4\%), as well as in 12 more municipalities. The municipalities with the largest population reduction were: Crna Trava (35\%), Majdanpek, Gadžin Han, Ražanj, Babušnica, Medveđa and Trgovište (more than 20\%).

Table 1 - Increase / decrease of population in NUTS 3 regions of Serbia in period 1991-2015

\begin{tabular}{|c|c|c|c|c|c|c|c|c|}
\hline $\begin{array}{l}\text { NUTS } 3 \\
\text { regions }\end{array}$ & 1991 & 2009 & 2010 & 2011 & 2012 & 2013 & 2014 & 2015 \\
\hline Belgrade & $1,552,732$ & $1,630,582$ & $1,639,505$ & $1,658,151$ & $1,664,218$ & $1,669,552$ & $1,675,043$ & $1,679,895$ \\
\hline West Bačka & 221,152 & 195,573 & \begin{tabular}{|l|}
193,331 \\
\end{tabular} & 188,447 & 186,188 & 183,967 & 181,780 & 179,639 \\
\hline $\begin{array}{l}\text { South } \\
\text { Bačka }\end{array}$ & 319,471 & 300,874 & 298,400 & 294,043 & 291,686 & 289,766 & 287,739 & 285,597 \\
\hline $\begin{array}{l}\text { South } \\
\text { Banat }\end{array}$ & 565,639 & 607,282 & 608,725 & 615,190 & 615,616 & 616,111 & 616,378 & 616,722 \\
\hline $\begin{array}{l}\text { North } \\
\text { Banat }\end{array}$ & 173,839 & 153,708 & 151,982 & 147,890 & 146,274 & 144,672 & 143,144 & 141,612 \\
\hline $\begin{array}{l}\text { Middle } \\
\text { Banat }\end{array}$ & 217,684 & 193,067 & 191,031 & 187,860 & 186,013 & 184,311 & 182,555 & 180,772 \\
\hline Syrmia & 333,305 & 325,734 & 323,197 & 312,530 & 310,418 & 308,512 & 306,717 & 304,889 \\
\hline Zlatibor & 325,997 & 296,858 & 294,400 & 286,825 & 284,216 & 281,475 & 278,771 & 276,210 \\
\hline & & & & & & & & 168,290 \\
\hline Mačva & 344,882 & 310,839 & 307,904 & 299,345 & 296,456 & 293,598 & 290,747 & 288,034 \\
\hline Moravica & 231,829 & 215,422 & 213,939 & 212,752 & 211,042 & 209,365 & 207,568 & 205,631 \\
\hline Pomoravlje & 236,078 & 216,186 & 214,260 & 214,872 & 212,808 & 210,795 & 208,683 & 206,491 \\
\hline Rasina & 272,334 & 244,241 & 242,040 & 242,300 & 239,866 & 237,492 & 234,990 & 232,335 \\
\hline Raška & & & & & & & & 307,408 \\
\hline Šumadija & 306,420 & 289,496 & 288,151 & 293,422 & 292,035 & 290,541 & 289,175 & 287,784 \\
\hline Bor & 155,421 & 132,464 & 130,557 & 125,285 & 123,616 & 121,909 & 120,156 & 118,384 \\
\hline Braničevo & 205,334 & 189,556 & 187,341 & 183,860 & 181,666 & 179,451 & 177,217 & 174,888 \\
\hline Zaječar & 153,459 & 124,423 & 122,605 & 120,216 & 118,401 & 116,665 & 114,901 & 113,131 \\
\hline Jablanica & 250,133 & 227,116 & 224,776 & 216,583 & 214,184 & 211,890 & 209,691 & 207,500 \\
\hline Nišava & 391,427 & 374,017 & 372,670 & 376,522 & 374,371 & 372,220 & 370,215 & 368,088 \\
\hline Pirot & 116,717 & 95,861 & 94,575 & 92,614 & 91,358 & 90,216 & 89,191 & 88,095 \\
\hline Podunavlje & 214,770 & 203,118 & 201,908 & 199,497 & 197,963 & 196,285 & 194,701 & 192,934 \\
\hline Pčinja & 215,014 & 228,254 & 227,554 & 205,811 & 204,748 & 203,578 & 202,425 & 201,170 \\
\hline Toplica & 110,732 & 94,570 & 93,513 & 91,832 & 90,707 & 89,574 & 88,513 & 87,414 \\
\hline
\end{tabular}

Source: P3C, 2016.

The chain index of population growth was highest in Raška (110\%), Belgrade (109\%) and South Bačka (108\%), and the smallest in Zaječar (73\%), Pirot $(76 \%)$ and Bor district $(75 \%)$. Average chain index of increase or decrease in the number of inhabitants was $85 \%$. 


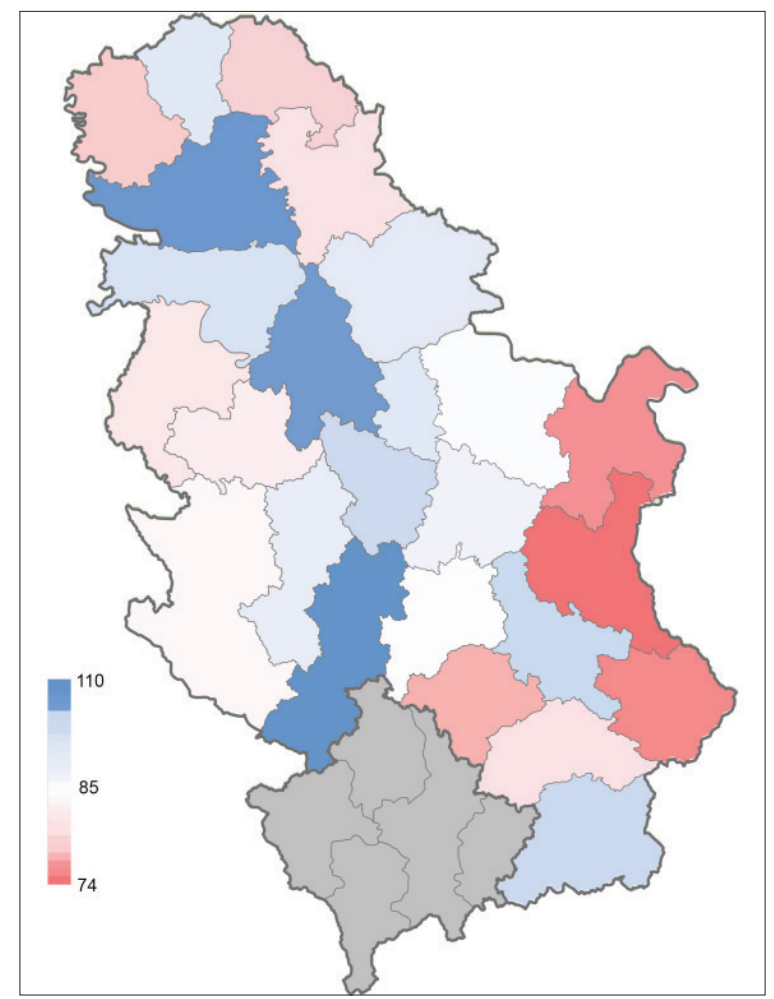

Figure 4 - Chain index of increase/decrease of popula-

tion by districts of Serbia in period 1991-2015 (\%)

Source: Map processed by paper authors based on P3C, 2016

Changes in the number of inhabitants of Serbia, in period 2002-2011 were mostly affected by natural increase. In the region of South and East Serbia and Šumadija and West Serbia, emigration to developed cities of Serbia and the regions of Europe has influenced migration as a significant component of natural growth (Table 2). Due to the negative rates of natural increase and emigration of the young population, some regions will remain without a functional population contingent (fertile population and working population) (Ђурђев и Арсеновић, 2015). Since Serbia as an underdeveloped country can't "import" labour and stimulate migration from neighbouring countries, the solution to the problem lies in increasing natural growth and reducing the emigration of the working population to other countries. 
Table 2 - Component of demographic changes in Serbia by regions (NUTS 2 level) in period 2002-2011

\begin{tabular}{|c|c|c|c|c|c|}
\hline \multirow[b]{2}{*}{ Spatial unit } & \multirow{2}{*}{$\begin{array}{c}\text { Population } \\
\text { 2002-2011 }\end{array}$} & \multicolumn{2}{|c|}{ Absolute share } & \multicolumn{2}{|c|}{ Relative share (\%) } \\
\hline & & $\begin{array}{l}\text { Natural } \\
\text { growth }\end{array}$ & Migrations & $\begin{array}{l}\text { Natural } \\
\text { growth }\end{array}$ & Migrations \\
\hline NUTS 2 region & $-311,139$ & $-297,377$ & $-13,762$ & 95,6 & 4,4 \\
\hline Belgrade & 83,316 & $-32,648$ & 115,964 & - & 100 \\
\hline Vojvodina & $-100,183$ & $-94,303$ & $-5,880$ & 94,1 & 5,9 \\
\hline Šumadija and West Serbia & $-105,184$ & $-79,636$ & $-25,548$ & 75,7 & 24,3 \\
\hline South and East Serbia & $-189,088$ & $-90,790$ & $-98,298$ & 48,0 & 52,0 \\
\hline Kosovo and Metohija & - & - & - & - & - \\
\hline
\end{tabular}

Source: P3C, 2002, 2016.

Between the districts (NUTS 3) in Serbia, differences in the unemployment rate and the trend of reducing the share of the unemployed in the total number of inhabitants in the period 2005-2015 were determined. In 2005, there were differences at the regional level between Belgrade, Kolubara, Šumadija, Braničevo, Bor, Zaječar and Pomoravlje regions on the one hand and other regions. Braničevo, Belgrade and Bor regions are distinguished as regions with the smallest and Jablanica, Mačva and West Bačka regions with the highest unemployment rates. Unemployment problems in Vojvodina were associated with unresolved privatizations of large industrial companies from agro-complex as well as low competitiveness on the agricultural product market. Unemployment in the South Serbia region is related to the long-standing development problems of all segments of the economy. With the lowest rates of unemployment, are regions rich in mineral resources, with developed extractive industries, energy companies and cement plants.

Period of 2005-2015 was time without equalization of regional differences between the regions of Serbia, but a different spatial distribution of the unemployment rate. In the regions of Vojvodina, Belgrade and Šumadija and West Serbia, the unemployment rate has been reduced while in the region of East and South Serbia it has been increased. Decrease in unemployment in Moravica and Zlatibor region has been influenced by the increase in export oriented fruit production (plum, malting, etc.) as well as the development of tourism and services. In Vojvodina, unemployment has decreased: increasing competition and establishing new companies in the agrarian sector, concentrating foreign companies around corridors 10 and 7, growing tourism, catering and city services. 
In addition to the aforementioned direct factors, the reduction of unemployment indirectly accelerated demographic aging, the emigration of the younger middle-aged and the overall decrease in the young population's contingent.

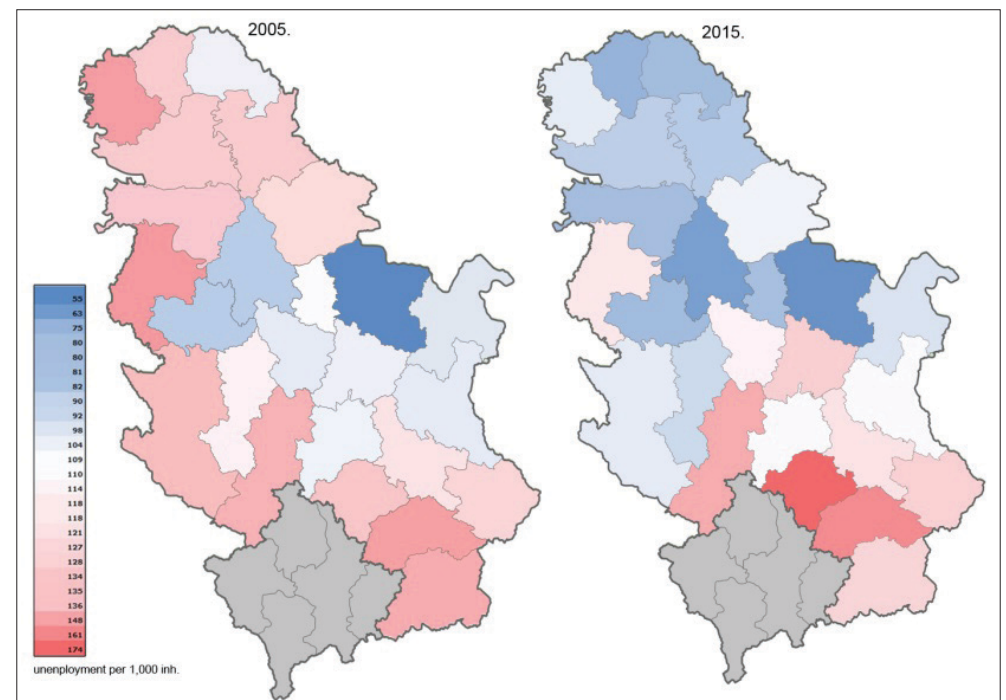

Figure 5 - Number of unemployed inhabitants from working contingent per 1,000 inhabitants at 2005 and 2015. Source: Map processed by paper authors based on P3C, 2006, 2016

GINI index in the Republic of Serbia has increased from $25.4 \%$ in 1996 to $54.9 \%$ in 2015 . The increase in the inequality index points to a lower degree of decentralization of the region, or the strengthening of economic power in administrative centres. In the national income share per cities, in 2015, six cities accounted for $50 \%$ of the share: Belgrade (34.2\%), Novi Sad (6.4\%), Niš (3.3\%), Kragujevac (2.3\%), Subotica (1,7\%) and Pančevo (1.6\%) (P3C, 2016).

After 2000, there is a noticeable increase in the relative level of development of the Belgrade and South Bačka regions. At the intraregional level, there are major disproportions in the development of the municipalities of Belgrade, Zlatibor, Moravica, Šumadija, Jablanica and Pčinja regions where the GINI index was more than $25 \%$. The least inequalities between local governments were recorded in West Bačka, North Bačka, Bor, Podunavlje and Toplica regions. 


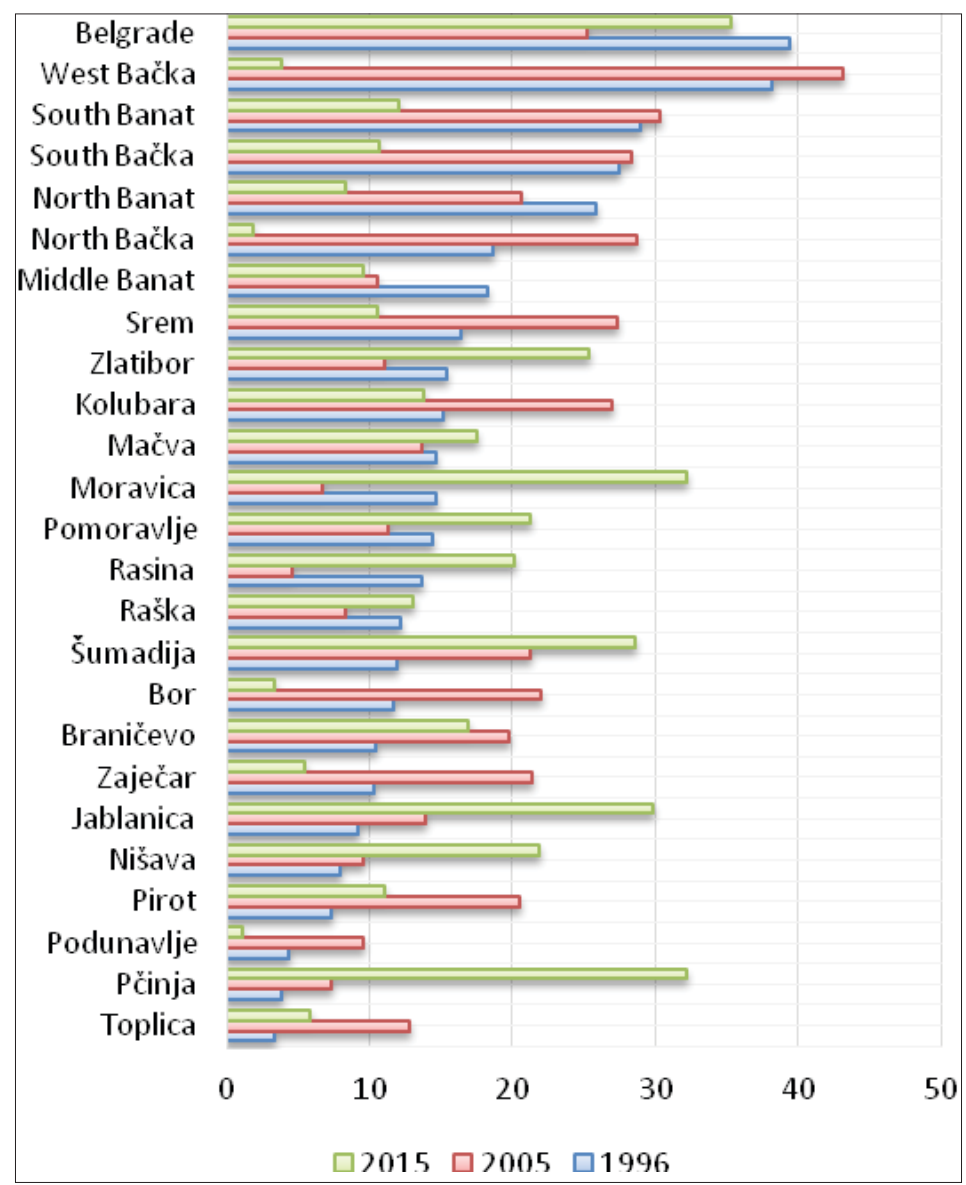

Figure 6 - Intraregional GINI index by regions for 1996, 2005 and 2015 Source: data processed by authors

Theory of human capital predicts that real wages are higher in regions with higher concentration of human capital, where workers are better educated, have more experience, and where there are small concentrations of workers earning less (women, ethnic minorities and young workers). For example, if workers in one region are young and less educated or if there is a minority group that earns less, the earnings will be less due to regional factors but because of these characteristics (Beenstock \& Felsenstein, 2008). Regarding case of Serbia, this theory is partially confirmed. The Belgrade and West Bačka regions with a large share of the highly educated population 
have high salaries, less unemployed and people's income far above the average of the Republic. On the other hand, the Nišava and Šumadija regions that have a high share of the highly educated population face economic problems and high unemployment, which means that the young highly educated population is forced to migrate or seek work outside their education profile.

Table 3 - Regional inequality by NUTS 2 regions of Serbia according to the gross domestic product expressed in the parity of purchasing power (PPP) $(E U=100)$

\begin{tabular}{|l|c|c|c|c|}
\hline NUTS 2 regions & $\mathbf{2 0 0 9}$ & $\mathbf{2 0 1 0}$ & $\mathbf{2 0 1 1}$ & $\mathbf{2 0 1 3}$ \\
\hline Belgrade & 65 & 61 & 60 & 60 \\
\hline Vojvodina & 34 & 33 & 35 & 35 \\
\hline Šumadija and West Serbia & 26 & 24 & 23 & 23 \\
\hline South and East Serbia & 23 & 22 & 22 & 21 \\
\hline Kosovo and Metohija & - & - & - & - \\
\hline Max.value/Min.value: & 2.83 & 2.77 & 2.77 & 2.85 \\
\hline
\end{tabular}

Source: MRRLS, 2013; MПPC, 2015.

Education is the basis of regional development in the 21st century. Accessibility of information, teaching innovation, student mobility, students and professors have made knowledge more effective than formal education. Investing in education system and creating a highly qualified labour market is a priority for highly developed countries and regions. The educational structure of the population is analysed according to the level of education of the population older than 15 years and is in direct correlation with the structure of schools and university institutions. There are significant inequalities in all areas of Vojvodina, Belgrade and the Šumadija region, on the one hand, in relation to the Jablanica, Toplica and Pčinja regions on the other (Table 4). The share of the population with incomplete elementary school education of more than $20 \%$ is distinguished by the Braničevo and Zaječar regions. The population with completed elementary school in 2015 was the second largest contingent in the educational structure. At the level of NUTS 3 regions, it is in correlation with the contingent of incomplete education, so the largest share of the population with elementary education had the same regions. The highest level of unification in Serbia by the regions is according to contingent of the secondary education population in the total. In most areas, secondary education has about half the population over 15 years of age. 
In the case of Braničevo, Zaječar, Kolubara and Pomoravlje regions, low unemployment rates and the educational structure of the population point to the desirability of low-skilled labour in large enterprises of extractive industries, agriculture, as well as in workplaces where school education is not a priority.

Table 4 - Educational profile of the population of Serbia by NUTS 3 regions of 2015 (\%)

\begin{tabular}{|l|c|c|c|c|c|c|c|}
\hline \multicolumn{1}{|c|}{$\begin{array}{c}\text { NUTS 3 } \\
\text { regions }\end{array}$} & $\begin{array}{c}\text { Without } \\
\text { elementary } \\
\text { school }\end{array}$ & $\begin{array}{c}\text { Incomplete } \\
\text { elementary } \\
\text { school }\end{array}$ & $\begin{array}{c}\text { Elementary } \\
\text { school }\end{array}$ & $\begin{array}{c}\text { High } \\
\text { school }\end{array}$ & $\begin{array}{c}\text { Higher } \\
\text { Education }\end{array}$ & College & Unknown \\
\hline Belgrade & 1.2 & 4.1 & 13.9 & 52.5 & 8.2 & 19.6 & 0.5 \\
\hline West Bačka & 2.5 & 11.2 & 22.7 & 52.6 & 4.0 & 6.8 & 0.2 \\
\hline South Banat & 2.7 & 11.9 & 23.7 & 49.3 & 5.1 & 7.0 & 0.3 \\
\hline South Bačka & 2.1 & 7.8 & 18.6 & 52.0 & 5.4 & 13.9 & 0.2 \\
\hline North Banat & 2.0 & 14.8 & 25.5 & 46.7 & 4.6 & 6.1 & 0.3 \\
\hline North Bačka & 1.6 & 11.5 & 24.2 & 49.4 & 5.0 & 8.1 & 0.2 \\
\hline Midlle & 2.6 & 12.2 & 22.8 & 49.5 & 4.8 & 7.7 & 0.5 \\
\hline Banat & 2.7 & 11.5 & 21.7 & 53.0 & 4.4 & 6.4 & 0.3 \\
\hline Syrmia & 3.7 & 12.6 & 23.8 & 48.5 & 4.6 & 6.5 & 0.3 \\
\hline Zlatibor & 3.8 & 17.5 & 24.2 & 44.0 & 4.3 & 6.1 & 0.2 \\
\hline Kolubara & 4.3 & 15.4 & 22.5 & 47.5 & 4.2 & 5.8 & 0.3 \\
\hline Mačva & 2.5 & 13.0 & 21.8 & 50.2 & 4.7 & 7.7 & 0.2 \\
\hline Moravica & 3.5 & 17.6 & 24.7 & 43.1 & 4.5 & 6.1 & 0.5 \\
\hline Pomoravlje & 3.9 & 15.4 & 23.9 & 44.1 & 5.4 & 7.1 & 0.4 \\
\hline Rasina & 3.6 & 10.2 & 26.8 & 46.7 & 4.5 & 7.5 & 0.7 \\
\hline Raška & 2.0 & 11.9 & 20.0 & 51.6 & 5.5 & 8.8 & 0.2 \\
\hline Šumadija & 4.0 & 18.1 & 24.5 & 41.9 & 4.6 & 6.0 & 0.9 \\
\hline Bor & 3.9 & 20.4 & 30.5 & 35.8 & 3.7 & 4.8 & 0.9 \\
\hline Braničevo & 2.6 & 20.7 & 24.7 & 40.8 & 4.8 & 6.2 & 0.2 \\
\hline Zaječar & 5.8 & 15.5 & 20.2 & 47.2 & 4.8 & 6.0 & 0.5 \\
\hline Jablanica & 11.0 & 18.7 & 49.4 & 6.3 & 11.6 & 0.5 \\
\hline Nišava & 15.9 & 24.5 & 44.1 & 5.7 & 7.0 & 0.2 \\
\hline Pirot & 13.3 & 24.7 & 48.2 & 4.6 & 6.0 & 0.5 \\
\hline Podunavlje & 2.8 & 12.6 & 25.6 & 44.0 & 5.1 & 7.1 & 0.3 \\
\hline Pčinja & 13.9 & 24.0 & 45.1 & 5.0 & 5.7 & 0.4 \\
\hline Toplica & 5.9 & 13.9 & \\
\hline Source: P3C, & 2016.9 & & & \\
\hline
\end{tabular}

Source: P3C, 2016.

Poverty as an indicator of regional inequality in Serbia is in correlation with economic indicators, the labour market structure and educational struc- 
ture of the region. For the analysis of regional inequality, data obtained from surveys conducted on the sample are available so they can't be considered as fully relevant. In 2002, the share of the poor among the surveyed population was double-digit in all regions of Serbia with the highest in Southeast Serbia and the minimum in Belgrade. On the sample from 2007, the share of the poor was reduced in many cases, except in the region of East Serbia. After 2007, there was a new increase in the share of the poor in all regions of Serbia. From 2010 to the present, the share of the poor population is stagnant. Among other regions, it is still the poorest in region of East and South Serbia. The poverty rate in 2014 in urban areas (6.7\%) was twice lower than in rural area (12.2\%). Nevertheless, there has been a decrease in inequality between the share of the poor in urban and rural regions of Serbia (from 2.04 in 2012 to 1.82 in 2014) (Mijatović, 2014). Although there is a smaller share of the poor in the cities of Serbia, it is obvious that high living costs make life difficult for their residents. Suburbs in large cities are characterized by a large number of unemployed who migrated from other regions of Serbia. Poverty vulnerable groups (PVG) are considered as multi-member families of newly settled residents, among whom there are few employed and more dependent and inactive members.

Table 5 - Share of the poor in total population (\%) in the regions of Serbia 2002-2014. years

\begin{tabular}{|l|c|c|c|c|}
\hline Spatial unit & $\mathbf{2 0 0 2}^{\mathbf{3}}$ & $\mathbf{2 0 0 7}$ & $\mathbf{2 0 1 0}^{\mathbf{4}}$ & $\mathbf{2 0 1 4}$ \\
\hline Belgrade & 10.8 & 3.1 & 5.3 & 4.7 \\
\hline Vojvodina & 12.4 & 6.1 & 6.8 & 7.8 \\
\hline West Serbia & 16.5 & 8.4 & - & 7.6 \\
\hline Central Serbia & 16.2 & 8.4 & 12.0 & 11.4 \\
\hline Šumadija & 13.8 & 3.7 & - & 7.6 \\
\hline East Serbia & 12.9 & 10.1 & - & 16.4 \\
\hline Southeast Serbia & 21.2 & 13.3 & - & 16.4 \\
\hline
\end{tabular}

Source: Крстић, 2008; Mijatović, 2014; P3C, 2011.

\section{Conclusion}

The research of inequality in Serbia imposes several groups of indicators, among which they have been demographic, social and economic. The lack of

\footnotetext{
${ }^{3}$ Data for 2002 are 2007 is given according methodology of author.

${ }^{4}$ Data for 2010 is given for macro-regions of Serbia.
} 
research is a time-limited and spatially limited database. Data on inequalities in the region can be an integral geographic database based on strategies and measures for mitigating regional inequalities. Identifying indicators, but also problems of inequality, led to a policy of reducing regional inequalities in the period 1991-2015. However, although there are clearly defined goals and strategic documents of the Republic of Serbia, harmonized with the documents of the most developed countries, the policy of reducing regional inequality was more declarative and sporadic than efficient and integral.

Investigated indicators of inequality in Serbia point to an economically, socially and demographically polarized space in which two distinct forms are distinguished: 1 - regions with maximum population density, high incomes and a high share of highly educated population and 2 - deserted regions with minimal income, old population and the problem of total depopulation. Due to the concentration of population as well as employees in public sector or large state-owned companies, the differences between regional centres and the rural hinterland are deepening. Some municipalities, due to the low level of competence and scarce budget, have long since been unable to manage the developmental problems they face. Centralization of political and fiscal power in Belgrade and Novi Sad, as well as an incomplete regionalization process, in addition to political, caused a concentration of economic, demographic and social power in NUTS 3 regions of Belgrade and South Bačka. As a result, 32\% of the population, of which $13-19 \%$ of the highly educated, with an average unemployment rate of 75 per 1,000 inhabitants and about $5 \%$ of the poor, represent, for now, hardly reachable segments of development for other regions in Serbia. Among measures to reduce inequality, decentralization is highlighted and new territorial organization of Serbia, which provides for greater political and fiscal competencies in the regions and local self-governments, as well as a higher level of competitiveness for the holders of regional economy.

\section{Acknowledgements}

The paper is the result of the research within the project no. 176008 funded by the Ministry of Education and Science of the Republic of Serbia. 


\section{References}

Annoni, P., \& Djikstra, L. (2013). EU Regional Competitiveness Index RCI 2013. Brussels: European Commission, Joint Research Centre, Institute for Security and Protection of the Citizens.

Beenstock, M., \& Felsenstein, D. (2008). Regional heterogeneity, conditional convergence and regional inequality. Regional Studies, 45(4), 475-488.

Bohn, U., Gollub, G., \& Hettwer, C. (eds.) (2000). Karte der natürlichen Vegetation Europas/Map of the Natural Vegetation of Europe Maßstabe/Scale 1:2 500 000 (2 Bände / 2 Volumes: Legende / Legend; Karten / Maps [9 Blätter/sheets]). Münster: Landwirtschaftsverlag.

Borgegård, L-E., Håkansson, J., \& Malmberg, G. (1995). Population redistribution in Sweden. Geografiska Annaler: Series B, Human Geography, 77(1), 31-45.

Bradford, M.G., \& Kent, A. (1977). Human geography: evolution of revolution. Oxford, UK: Oxford University press.

Canaleta, C.G., Pascual Arzoz, P., \& Rapún Gárate, M. (2004). Regional economic disparities and decentralisation. Urban Studies, 41(1), 71-94.

CORINE (2012). Corine land cover map. Retrived from http://land.copernicus.eu/pan-european/ corine-land-cover

Deiwiks, C., Cederman, L., \& Gleditsch, K.S. (2012). Inequality and conflict in federations. Journal of Peace Research, 49, 289-304.

EEA (2016). Europe's environment agency report 1/2002. Retrieved from https://www.eea.europa.eu/publications/report_2002_0524_154909\#tabfigures-used

Ezcurra, R., \& Pascual, P. (2008). Fiscal decentralization and regional disparities: evidence from several European Union countries. Environmental Planning A, 40, 1185-1201.

GEOLISS (2017). Geological Information System of Serbia. Retrieved from http://geoliss.mre.gov.rs

Zeremski, M. (1990). Geomorfološka (morfostrukturna) karta Srbije. Beograd: Geografski institut „Jovan Cvijić”; Odbor za geodinamiku SANU.

Lessmann, C. (2012). Regional inequality and decentralization - an empirical analysis. Environment and Planning A, 44(6), 1363-1388. 
Metzger, M.J., Bunce, R.G.H., Jongman, R.G.H., Mücher, C.A., \& Watkins, J.W. (2005). A climatic stratification of the environment of Europe. In: Metzger, M.J. (ed.). European vulnerability to global change - a spatially explicit and quantitative assessment (pp. 101-128). Wageningen: Wageningen University.

Milovanović, B., Ducić, V., Radovanović, M., \& Milivojević, M. (2017). Climate regionalization of Serbia according to Köpen climate classification. Journal of Geographic Institute "Jovan Cvijić", 67(2), 103-114.

Mücher, C.A., Klijn, J.A., Wascher, D.M., \& Schaminée, J.H. (2010). A new European Landscape Classification (LANMAP): a transparent, flexible and user-oriented methodology to distinguish landscapes. Ecological indicators, 10(1), 87-103.

Mijatović, B. (2014). Siromaštvo u Srbiji 2014. godine. Beograd: Vlada RS, Tim za socijalno uključivanje i smanjenje siromaštva.

MRRLS (2013). Izveštaj o razvoju Srbije 2012. godine. Beograd: Ministarstvo regionalnog razvoja i lokalne samouprave.

Rodriguez-Pose, A., \& Gill, N. (2004). Is there a global link between regional disparities and devolution? Environment and Planning A, 36(12), 2097-2117.

Rosenmai, P. (2017, October 1). Homepage. Lorenz curve graphing tool $\mathcal{E}$ Gini coefficient calculator. Retrieved from http://www.peterrosenmai.com/ lorenz-curve-graphing-tool-and-gini-coefficient-calculator

SLCG (2011). Službeni list Crne Gore 42/2011. Retrieved from http:/ / www.sluzbenilist.me/SLOsnRezultati.aspx?tp=0\&yr=2011\&nvg=1,1,5

Stanners, D., \& Bourdeau, P. (eds.) (1995). Europe's environment - the Dobris assessment. Luxembourg: Office for Official Publication of the European Communities.

SGRS (2005). Službeni glasnik Republike Srbije 55/2005 i 71/2005. Retrieved from http://www.pravno-informacioni-sistem.rs/SlGlasnikPortal/slglrs/NP/overview

SGRS $(2009,2010)$ Službeni glasnik Republike Srbije 51/2009, 30/2010 i 42/2010. http://www.pravno-informacioni-sistem.rs/SlGlasnikPortal/slglrs/NP/overview

Shankar, R., \& Shah, A. (2003). Bridging the economic divide within countries: a scorecard on the performacne of regional policies in reducing regional income disparities. World Development, 31(8), 1421-1441.

Vresk, M. (1990). Grad u regionalnom i urbanom planiranju. Zagreb: Školska knjiga.

Wascher, D.M. (ed). (2005). European landscape character areas - typologies, cartography and indicators for the assessment of sustainable landscapes. Final Pro- 
ject Report as deliverable from the EU's Accompanying Measure project. Wageningen, The Netherlands: European Landscape Character Assessment Initiative (ELCAI), funded under the 5th Framework Programme on Energy, Environment and Sustainable Development (4.2.2).

Williamson, J.G. (1965). Regional inequality and the process of national development: a description of patterns. Economic Development and Cultural Change, 13, 1-84.

Ђурђев, Б. и Арсеновић, Д. (2015). Популациона динамика у међупописном периоду. У: Никитовић, Р. (ур.). Популащија Србије почетком 21. века - Попис становништва, домаћинстава и станова 2011. године. Београд: Републички завод за статистику.

Крстић, Г. (2008). Профил сиромаштва у Србији у периоду 2002-2007: Студија о животном стандарду. Београд: Републички завод за статистику Србије.

МПРС (2015). Извештај о привредном развоју Србије 2014. године. Београд: Министарство привреде.

РЗС (2002). Општине у Републици Србији 2002. године. Београд: Републички завод за статистику.

РЗС (2006). Општине у Републици Србији 2006. године. Београд: Републички завод за статистику.

РЗС (2011). Сиромаштво у Републици Србији, 2008-2010. године. ЛП20, бр. 117 Београд: Републички завод за статистику.

РЗС (2016). Општине и региони у Републиии Србији 2016. године. Београд: Републички завод за статистику.

РЗС (2017). Сиромаштво и социјална неједнакост, 2016. ПД10, бр. 087 Београд: Републички завод за статистику.

Тошић, Б., Лукић, В., и Ћирковић, М. (2005). Насеља неразвијених подручја Србије. Зборник радова Географског института "Јован Цвијић", 59(2), 1-19.

Тошић, Д. (2012). Принципи регионализациије. Београд: Универзитет у Београду, Географски факултет. 